\title{
Effect of Leaf Extract of Melia azedarach L. on the Testis Tissue of Albino Mice Mus musculus
}

\author{
Waad S. Al-Shaher \\ Department of Biology / College of Science/ Mosul University
}

E-mail: waad.alshaher@yahoo.com

(Received 15/5/2019; Accepted 16/9/2019)

\section{DOI: 10.33899/rjs.2020.164469}

\section{ABSTRACT}

Melia azedarach L. Leaf extract (200mg / kg body weight) every other day for 3,5,7 weeks on the reproductive organs of male mice and the fertility index were studied.

The treatment had no significant effect on body weight of groups B,C and D. The study exhibited that the average of new born and fertility were reduced to 2.66 and $66.66 \%$ in treatment groups for 7 weeks respectively.

The testes sections showed histopatholoical changes in all treated groups of male mice, and the degree of these changes ranged from medium to severe. The results indicated separated and necrotic of seminiferous tubules, testicular oedema, mixed and necrotic changes of spermatogenic cells, degeneration and loosing parts of the germinal epithelium of seminiferous tubules, bleeding of interstitial cells between the seminiferous tubules, clamping of spermatozoa in the seminiferous lumen, mixed the spermatogenic cells and thickness the sheath of tunica albuginea of the testis.

Keywords: Melia azedarch, Leaf extract, Testis, Fertility, Mice.

\section{INTRODUCTION}

Rodents because of their high rate of reproduction results in damage to the agricultural producution in India, by causing 5-10\% losses in different crops (Parshad and Ahmad,1996). Therefore they are considered to be the most destructive vertebrate pests.

Azadirachta indica a member from the same family Meliaceae as M.azedarach has been reported to have antifertility and anti implantation activity (Mukherjee et al.,1999; Khare et al.,1984;Roop et al.,2005).

M.azedarach leaves extract revealed the existence of alkaloids, flavonoids, glycoside, saponins, like compounds. Ethanolic extract of the leave demonstrated antioxidant, analgesic and anti-bacterial activity, possesses significant hepatoprotective activity (Asadujjaman et al.,2013; Nahak and Saho, 2010; Rana, 2010; Srinvasa et al.,2012). The ethanolic leaf extract of M.azedarach were investigated for fertility, there was abolition of libido in $100 \%$ of male rats (Choudhary et al.,1990).

Aqueous leaf extract of M.azedarach and Dodonaea viscosa showing antifertility activity in rats, but the antifertility activity of M.azedarach treated rats was higher than to D.viscsa treated group. The decreased sperm count and reproductive organ weights including the necrotic changes in the seminiferous tubules of testis suggesting the antifertility activity of plants (Kumar et al.,2013).

Some antifertility effects of leaf extracts of A.indica have been reported. The crude leaf extract of A.indica has been reported to cause reduced serum level of testosterone and luteinizing hormones (Parshad et al.,1994; Ragi et al.,2003) and reduced sperm counts with abnormal shaped spermatozoa (Awasthy,2001).

Azadiraction A-from A.indica leaves has been reported to cause reduction in the sperm functions parameters with increased abnormal sperms and performance test showed decrease the fertility in male albino rats (Aladakatti et al.,2011; Shaher, 2009; Shaher, 2013), Reported that leaf 
extracts of A. excelsa caused decrease in the number of spermatozoa and reduced the fertility index of treated male albino mice.

The objective of this study was to determine the effect of M.azedarach leaf extract on reproductive organ and their antifertility activity in male albino mice.

\section{MATERIALS AND METHODS}

\section{Plants:}

The green leaves of Melia azedarach L. were collected from trees growing at Adan area (Mosul) during April 2013.Leaves washed in running tap wate and dried under shade to powder using electric grinde

\section{Preparation of extracts:}

The method of plant extraction was used by (Shaher, 2009; Akpantah et al.,2010). 50g of the powdered leaves was macerated with $250 \mathrm{ml}$ of $75 \%$ ethanol alcoholic solution and left to stand at room temperature for 24 hours for thorough extraction of the plants' active components. These were then filtered with cheese cloth, and later the mixture was filtered through a whatman No.1 filter paper by suction and filterate was evaporated under vacuum at $40^{\circ} \mathrm{C}$ until completely dried yielding $7 \mathrm{~g}$ of brown oily M.azedarach, the extract was then refrigerated at $4^{\circ} \mathrm{C}$ until use for experiments. Distilled water was used to dilute this stock solution to concentrations of $200 \mathrm{mg} / \mathrm{kg}$ of body weight was based according to (Dharmalingam et al., (2014) who found that the aqueous and ethanolic extracts of Melia azedarach leaf $2500 \mathrm{mg} / \mathrm{kg}$ body weigh given orally did not produce mortality of any visible toxic signs in rats. The mode of administration was oral.

\section{Animals:}

In this study (20 male and 24 female albino mice Mus musculus) 3 months old, weighting (25-30g). The males were divided into 4 groups each one (5 males) isolated in plastic cages. Group A animals served as control group and the animal received $0-2 \mathrm{ml}$ distilled water, while groups of B, C, and D were the experimental groups, and were forced feeding orally dose $(200 \mathrm{mg} / \mathrm{kg})$ of body weight every other day for 3, 5, 7 weeks respectively. Were the females divided into 4 groups each one (six females) A1, B1, C1, D1. All groups were exposed to constant laboratory conditions, temperature was about $\left(25^{\circ} \mathrm{C} \pm 2\right)$ and light / dark cycle of $12: 12 \mathrm{~h}$, and fed with standard commercial diet and given water.

At the end of treatment period of each group, three males of control (group A)mated with six untreated nonpregnant females (groupA1)(one male with two females), while three of treated males of each group B, C, D, mated with six untreated nonpregnant females group B1, C1, D1 respctively to prove fertility. After one week the males were removed from cages. The pregnant female were observed daily after 3 weeks of gestation and the number of offspring from each female was recorded as soon possible after birth. The number of newborns of each group were recorded and the died borns after birth for determination of the average number of life borns and the fertility index. Other two males of each group were anesthetized with chloroform and dissected, testes were carefully isolated and fixed in neutral formalin (10\%)and dehydrated in ascending grades of ethanol(70\% to $100 \%)$, cleard in 2 changes of xylene, impregnated with 2 changes of molten paraffin wax, and finally embedded in wax. Testes sections of $5 \mu$ in thickness were cut with a microtom and staind with hematoxylin and eosin, loading with DPX.(Luna,1968; Al-Hajj, 2010).

The histological sections were photographed using light microscope with digital camera.

\section{RESULTS}

The effects of oral administration dose of ethanol leaf extracts of Melia azedarach $(200 \mathrm{mg}$ $/ \mathrm{kg}$ of b.wt.) every other day on body weigh, reproductive organs and fertility of male mice for 3,5,7 weeks were investigated.

The control group showed significant increased of body weight after 7 weeks, while treated male mice were observed no significant changes in body weight $(\mathrm{p}<0.05)$ at different periods of treatment (Table 1) 
Table 1: Shows effect of Melia azedarach leaf extracts at dose $200 \mathrm{mg} / \mathrm{kg}$ of $\mathrm{b} . \mathrm{wt}$. for different periods on male mice

\begin{tabular}{|c|c|c|c|}
\hline Groups & Duration of treatment & $\begin{array}{c}\text { Initial body weigh (gm) } \\
\text { (Mean } \pm \text { SE) }\end{array}$ & $\begin{array}{c}\text { Final body weigh (gm) } \\
\text { (Mean } \pm \text { SE) }\end{array}$ \\
\hline Group-A (control) & 0.0 & $27.2 \pm 0.83$ & $32.8 \pm 0.83$ \\
\hline Group-B & 3weeks & $37.6 \pm 0.24$ & $37.6 \pm 0.24$ \\
\hline Group-C & 5weeks & $36.4 \pm 0.24$ & $37.2 \pm 0.19$ \\
\hline Group-D & 7weeks & $34.4 \pm 0.24$ & $35.4 \pm 0.24$ \\
\hline
\end{tabular}

The mated mice (treated male and untreated females)exhibited decrease in the average number of live birth and the fertility index. The new born average decreased from 8.33 in control group to 2.66 in treated group for 7 weeks, while fertility index decreased from $100 \%$ in control group to $66.66 \%$ in treated group for 7 weeks (Table 2)

Table 2: Shows effect of M.azedarach leaf extracts on average number of new born and fertility index of mated mice

\begin{tabular}{|c|c|c|c|c|c|}
\hline Groups & $\begin{array}{c}\text { Dose and } \\
\text { duration } \\
\text { treatment of } \\
\text { males }\end{array}$ & $\begin{array}{c}\text { No. of Untreated } \\
\text { females of each group }\end{array}$ & $\begin{array}{c}\text { No. of females } \\
\text { pregnant }\end{array}$ & $\begin{array}{c}\text { Average No. } \\
\text { of the new } \\
\text { born }\end{array}$ & $\begin{array}{c}\text { Fertility } \\
\text { index } \%\end{array}$ \\
\hline Group- A & $0.2 \mathrm{ml}$ of D.W. & 6 & 6 & 8.33 & 100 \\
\hline Group-B & $\begin{array}{c}0.2 \mathrm{ml} \text { of 200mg } \\
\text { /kg b.wt. 3wks }\end{array}$ & 6 & 5 & 3.66 & 83.33 \\
\hline Group-C & $\begin{array}{c}0.2 \mathrm{ml} \text { of 200mg/kg } \\
\text { b.wt. 5wks }\end{array}$ & 6 & 4 & 2.66 & 66.66 \\
\hline Group-D & $\begin{array}{c}0.2 \mathrm{ml} \text { of 200mg/kg } \\
\text { b.wt. 7wks }\end{array}$ & 6 & 466.66 \\
\hline
\end{tabular}

\section{Histological changes:}

The testis section of control male mice group indicating normal seminiferous tubules and spermatogenesis, the seminiferous tubules were lined with (3-4) regular layers of spermatogenic cells at different stage of maturation and mature spermatozoa were observed in the lumen of the seminiferous tubules Fig. (1).

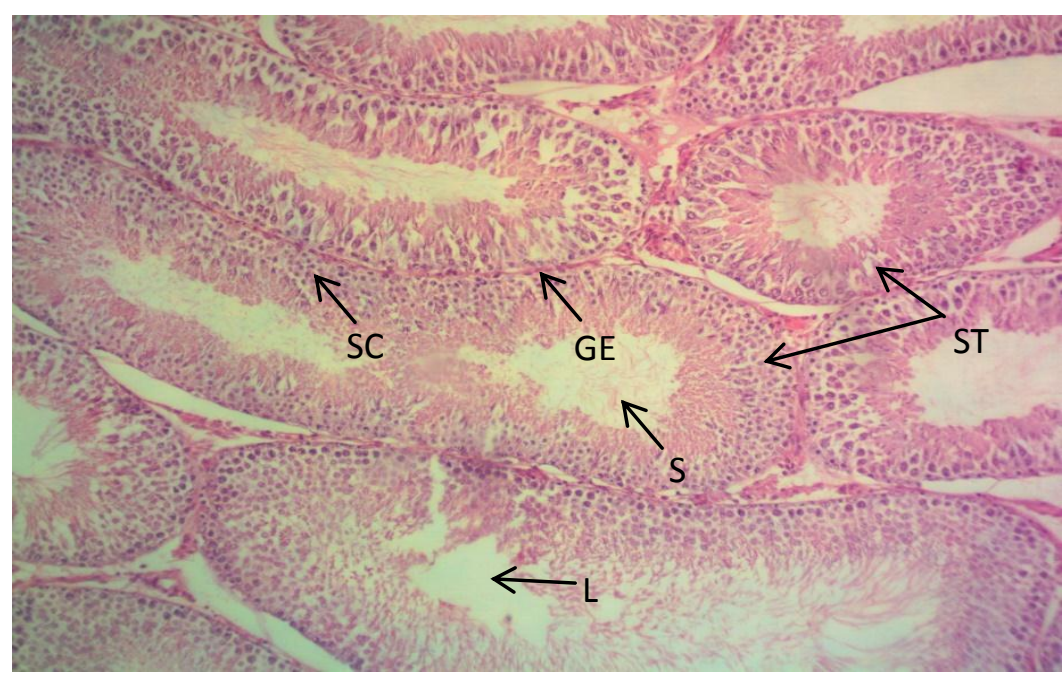

Fig. 1: photomicrograph of the testes of the control male mice, shows normal testis tissue, Seminiferous tubules (ST), Spermatogenic cells (SC), Lumen (L), Spermatozoa (S), Germinal epithelium layers (GE) . H\&E, 100x. 
The testis treated section of male mice for 3 weeks showed the seminiferous tubules separated and necrotic, testicular oedema, necrotic changes of spermatogenic cells, degeneration and loosening parts of the germinal epithelium of seminiferous tubules Fig. (2), with thickness sheath of tunica albuginea Fig. (3).

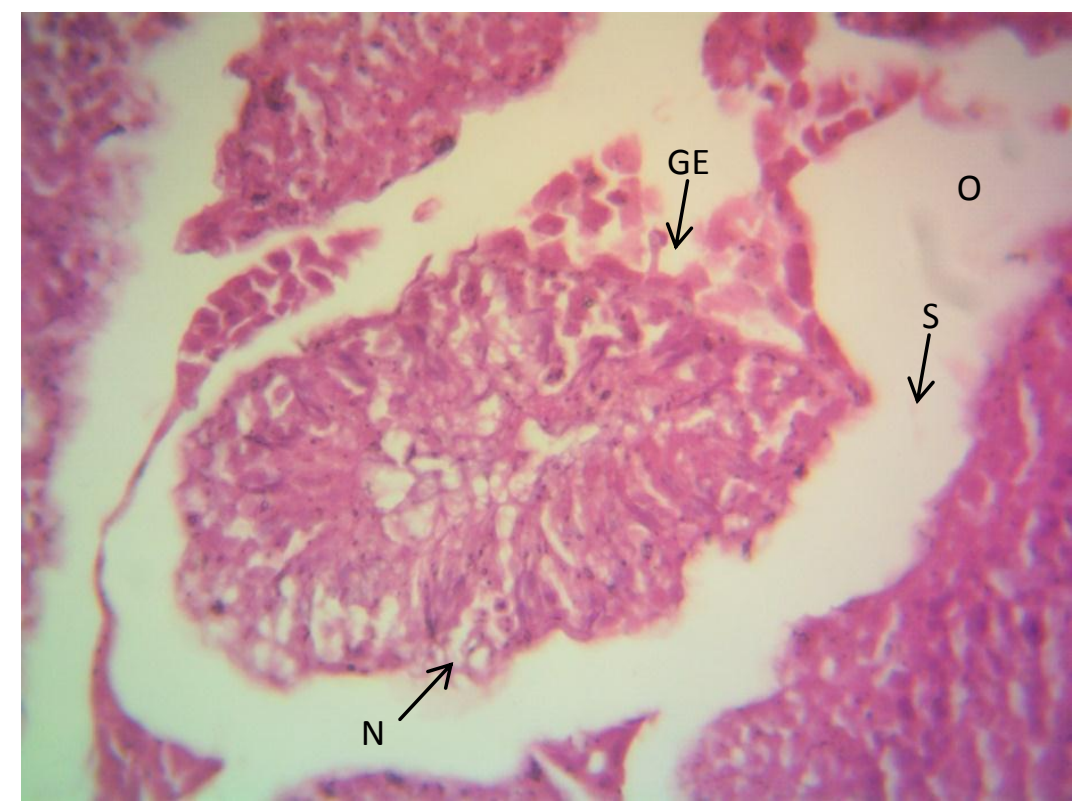

Fig. 2: Photomicrograph of treated group with $M$. azedarach for 3 weeks, showed the seminiferous tubules separated $(S)$ oedema $(O)$ necrotic changes of spermatogenic cell degeneration $(\mathrm{N})$ and loosening parts of the germinal epithelium of seminiferous tubules (GE). H\&E, 400x.

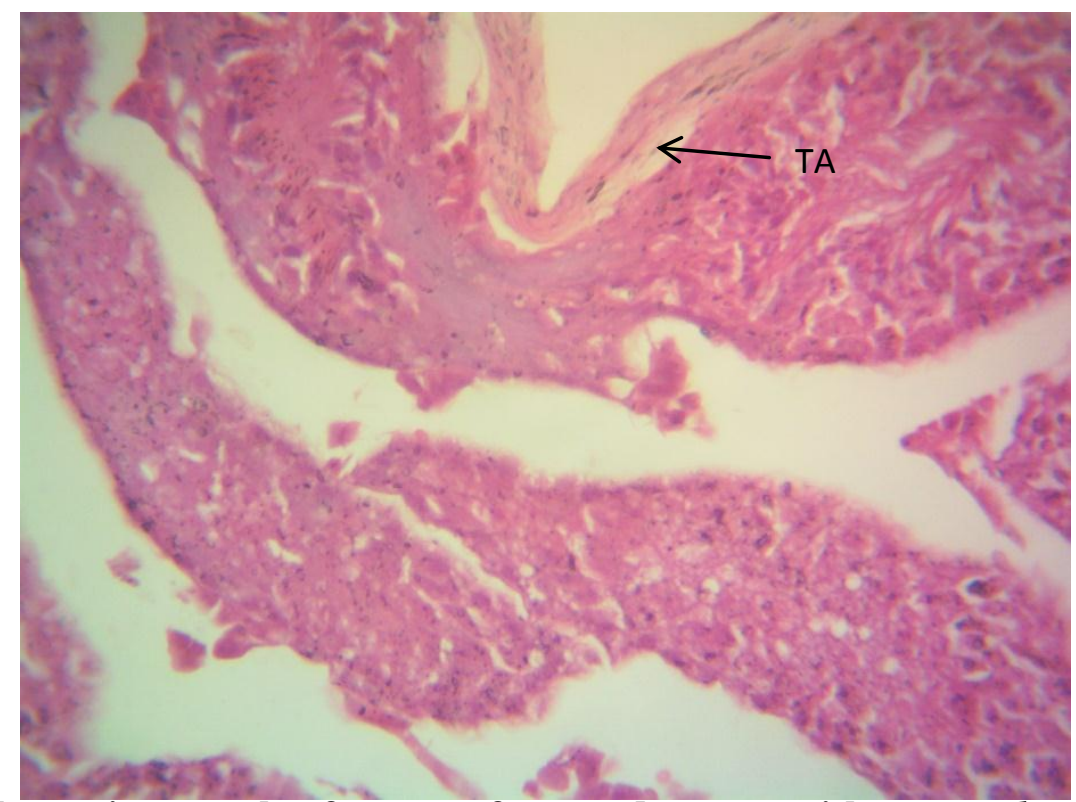

Fig. 3: Photomicrograph of testes of treated group with M. azedarach for 3 weeks showed thickness the sheath of tunica albuginea (TA), H\&E, X400.

The testis section of treated mice for 5 weeks showed mixed and necrosis of the spermatogenic cells, the gradual necrotic changes of seminiferous tubules, bleeding of interstitial cells between the seminiferous tubules, clumping of spermatozoa in the seminiferous lumen were observed Fig. (4), and thickness the sheath of tunica albuginea with edema Fig. (5). 


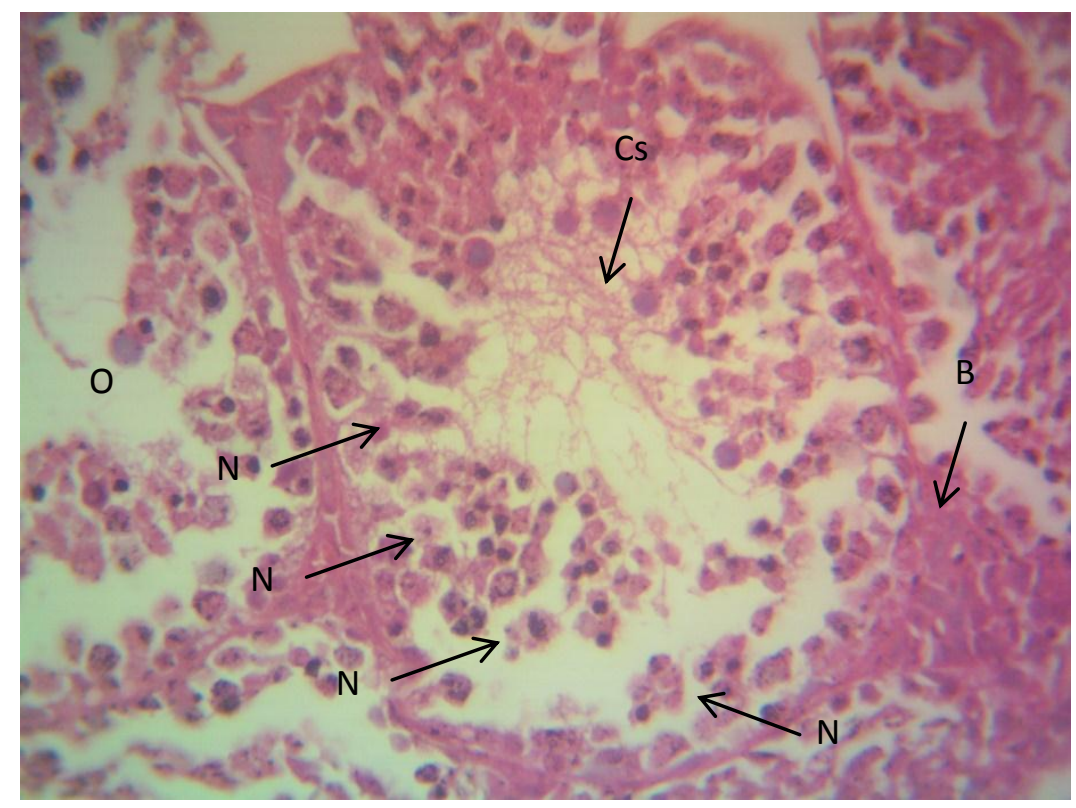

Fig. 4: Photomicrograph of testis of treated group with M. azedarach for 5 weeks showed necrosis of spermatogenic cells $(\mathrm{N})$, bleeding of interstitial cells between the seminiferous tubules $(B)$, oedema $(O)$, Clamping of spermatozoa in the lumen (Cs). H\&E,400x.

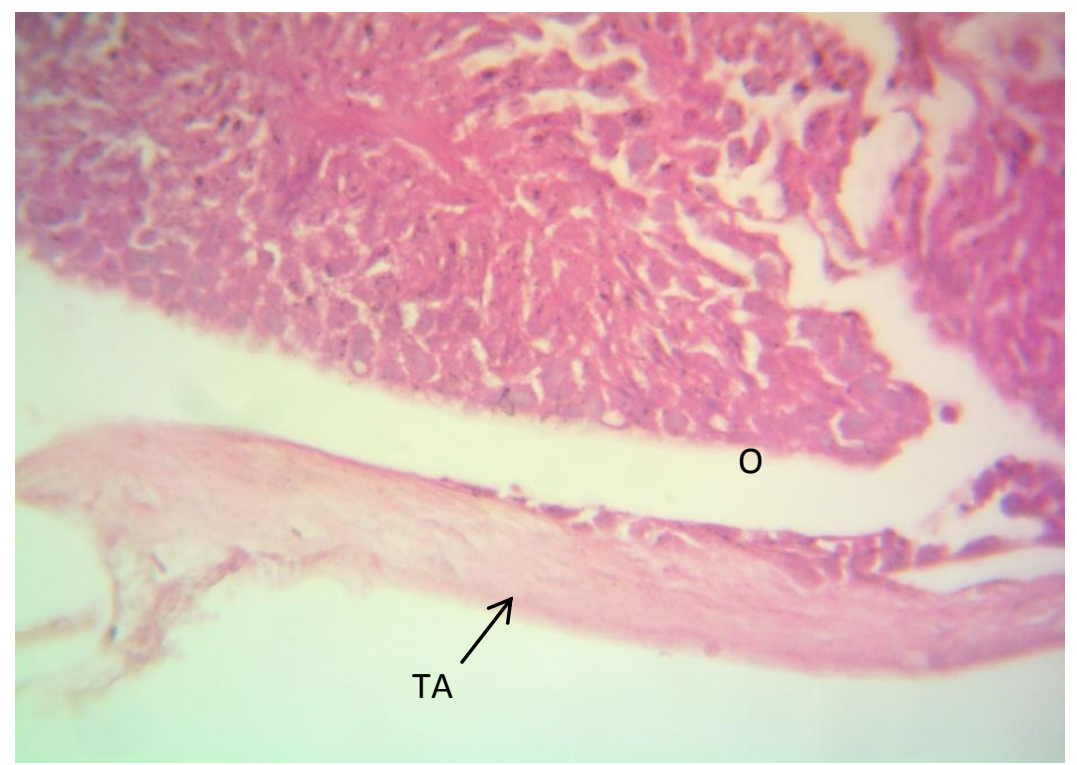

Fig. 5: photomicrograph of testis of treated group with $M$. azedarach for 5 weeks showed thickness of the sheath of Tunica albuginea with oedema $(O)$. H\&E,400x.

The testis section of treated mice for 7 weeks also showed mixed and necrosis of spermatogenic cells, necrotic changes of seminiferous tubules and testicular edema in the lumen of seminiferous tubules Fig. (6), thickness the sheath of tunica albuginea Fig.( 7) . 


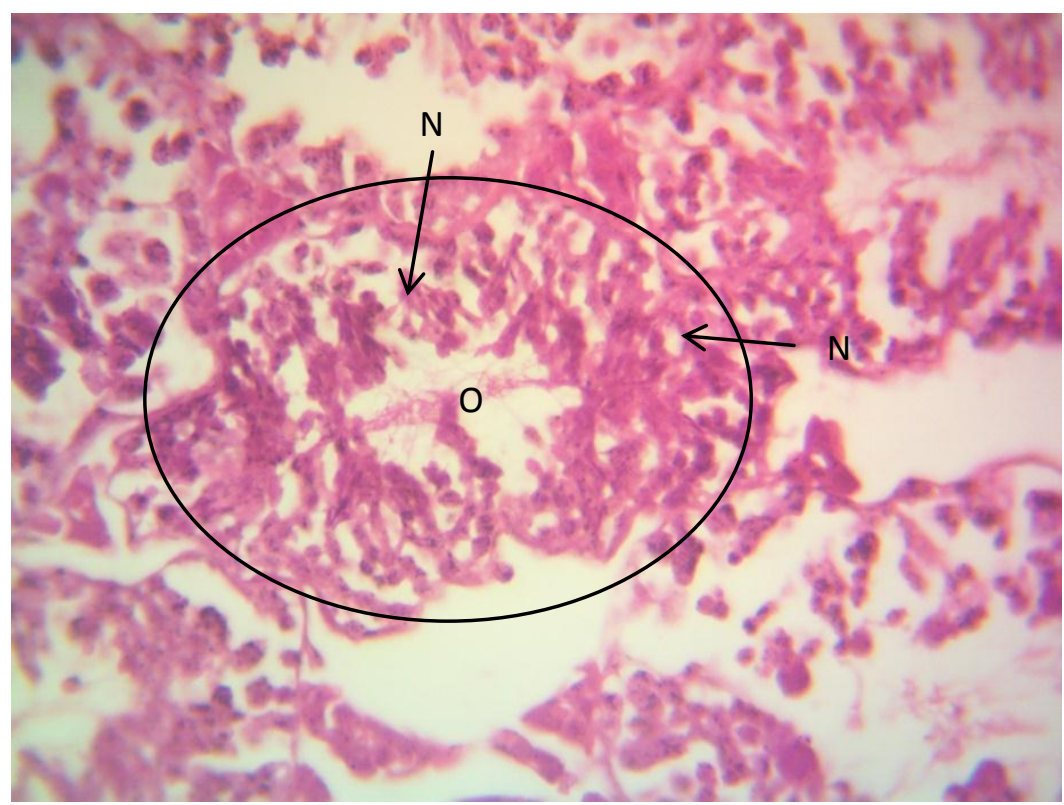

Fig. 6: Photomicrograph of testis of treated group with M. azedarach for 7 weeks showed mixed and necrotic of spermatogenic cells $(N)$, necrotic changes of seminiferous tubules (circle) and testicular oedema $(O)$, in the lumen of seminiferous tubules, H\&E, 400x.

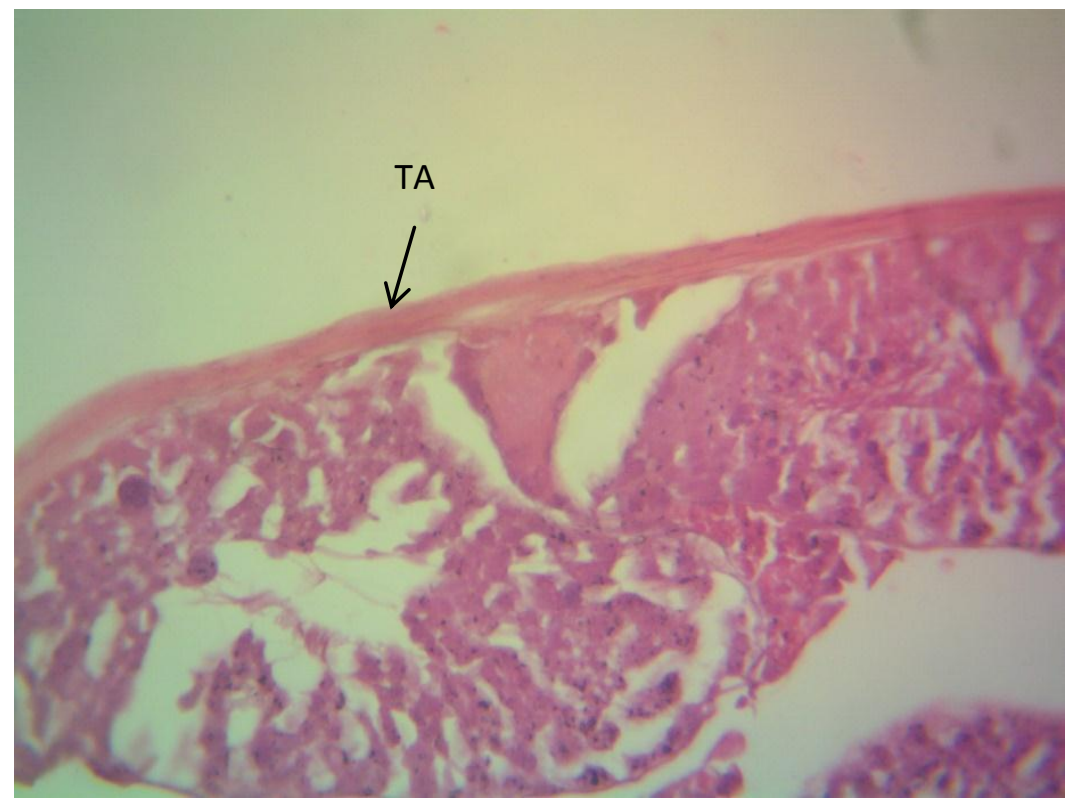

Fig. 7: photomicrograph of testis of treated group with $M$. azedarach for 7 weeks showed thickness of the sheath of tunica albugina (TA). H\&E, 400x.

\section{DISCUSSION}

The data recorded on the effect of M.azedarach leaf extract on body weight in adult male mice showed no significant changes at different period for during the present investigation (Table:1) supported the findings that aqueous leaf extract of A.indica administrated 50, 100, $200 \mathrm{mg}$ $/ \mathrm{kg}$ of b.w. for 28 days showed no effect on body weight and reproductive organs weight (Mishra and Singh, 2005), however the control and treated rats with aqueous leaf extracts of M.azedarach were abserved as they gained the body weight compare with initial weight (Kumar et al.,2013). 
In the current study the results indicated a reduction in fertility index of mated treated mice for $3,5,7$ weeks to $83.33,66.66,66.66$ respectively, the results observed decreased in the average number of new born (Table 2), this results due to the effect of leaf extracts on the different types of germ cells and the number, shape of spermatozoa. (Awasthy, 2001), recorded that crude leaf extract of A.indica reduced sperm count with abnormal shaped spermatozoa in mice. The similar results was observed by (Shaher, 2009; Mandal and Dhaliwal, 2007; Roop and Dhaliwal, 2015), that the fertility index and average number of embryos were considerably reduced in adult cycling rats after 18 days of treatment with hexane fraction of M.azedarach seed extract at dose $1 \mathrm{mg}, 3 \mathrm{mg}, 6 \mathrm{mg}$, $12 \mathrm{mg}, 24 \mathrm{mg} / \mathrm{kg}$ of b.wt. M. azedarach seed extract administered with $0.5 \mathrm{mg}, 1.0 \mathrm{mg}, 5 \mathrm{mg} / \mathrm{kg}$ of b. wt. for 18 days resulted in 100\% fertility reduction (Mandal and Dhaliwal, 2007).

In other study M.azedarach leaf extract were investigated for antifertility activity on male rats in oral dose of $100 \mathrm{mg} / \mathrm{kg}$ of b.wt. daily for 21 days, there was abolition of libido in $100 \%$ of males (Choudhary et al.,1990). Ethanolic extract of M.azedarach intercepted pregnancy in $60 \%$ and $75 \%$ of adult female rats (Keshri et al., 2003). (Enwren and Atmos, 2017), reported that is equally important for male and female in their reproductive stage to know that A.indica have some effect on fertility. According to the finding of (Kumar et al., 2013), the antifertility activity of aqueous extract of M.azedarach was higher than to the aqueous extract of D.viscosa.

The present study investigated that M.azedarach leaf extract showed mixed and necrosis of the spermatogenic cells, decreased and clumped the spermatozoa in the lumen of seminiferous tubules of treated groups. A.indica aqueous leaf extracts caused mixing of germ cell types(Mishra and Singh, 2005). (Kumar et al.,2013), showed decrease sperm count and clumped the spermatozoa of treated rats with M.azedarach and D.viscosa leaf extracts. (Awasthy,2001), recoded that crude leaf.

The present study investigated that the testis section of treated male mice group for 3 weeks showed separated and necrotic of the seminiferous tubules, necrotic changes of spermatogenic cells, degeneration, and loosening parts of germinal epithelium of seminiferous tubules Fig. (2), this study agreement with finding of (Kumar et al.,2013), who reported that the aqeous leaf extracts of M.azedarach and D.viscsa caused widely separated of seminiferous tubules with testicular edema as will as gradual necrotic changes of seminiferous tubules.on the other hand (Mishra and Singh, 2005), reported that the leaf extract of A. indica caused loosening of the germinal epithelium, degenerated appearance of germ cells.

The testis sections of treated male mice groups for $(5,7)$ weeks showed the same histopathological changes in addition of the other effects such as mixed and necrosis of the spermatogenic cells, bleeding of the interstitial cells between the seminiferous tubules and clumping of the spermatozoa in the seminiferous leumen Fig. $(4,7)$, this results corroborates the work of (Kumar et al.,2013), who observed clamping of spermatozoa in the seminiferous leumen of mice treated with leaf extracts of M. azedarach and D. viscose.

(Mishra and Singh, 2005), reported that A. indica leaf extract caused mixed of sgerm cells, occurrence of giant cells in male mice. The results of this study investigated that $M$. azedarach leaf extracts caused oedema, thickness the sheath of tunica albuginea Fig. $(3,5,7)$.

In conclusion the present study reveals that leaf extract of M.azedarach reduced the fertility index and caused different histopathological lesions in the testis of male mice.

\section{REFERENCES}

Akpantah, A.O.; Ekong, M.B.; Uruakpa, K.C.; Akpso, M.; Eluwa, M.A. (2010). Ekanem TB. Gonadal histo-morphologies and serum hormonal milieu in female rats treated with Azadirachta indica leaf extract. Indian J. Reprod. Med., 8(4), 185-190.

Aladakatti, R.H.; Sukesh, B.; Jadaramkunti, U.C.; Hiremath, M.B. (2011). Aspects of the antiandrogenic/ antifertility property of Azadirachtin- A from Azadirachta indica leaves in 
male albino rats: Effect on the biochemical and cuada epididymal sperm parameters. Recent Res. in Sci. and Technol. , 3(2), 34- 46.

Al-Hajj, H.A. (2010). "Optical Laporatory Preparation". $1^{\text {st }}$ Dar Al-Maseera. Aman. Jordan. 52 p.

Asadujjaman, M.D.; Saed, A.; Hossain, A.M.D.; Karmaka, K.U. (2013). Assessment of bioactivities of ethanolic extract of Melia azedarach (Meliaceae) leaves. J. Cost. Life Med., 1(2), 106- 110.

Awasthy, K.S. (2001). Genotoxicity of crude leaf extract of neem in male germ cells of mice. Cytobios. 106, 151- 164.

Choudhary, D.N.; Singh, J.N.; Verma, S.K.; Singh, B.P. (1990). Antifertility effects of leaf extracts of some plants in male rats. indian. J. Exp. Biol., 48, 714- 716.

Dharmalingam, S.R.; Rajkumar, M.R.; Kumarappan, C.K.; Ramamurthy, S.; Gopal, K.; Sweth, P.; Senthil, K.K. (2014). Antiurolthiasis activity of Melia azedarach L. leaf extracts in ethylene glycol-induced urolthiasis in male albino rats. Trop. J. Pharma., 13(3), 391-397.

Enwren, N.; Atmos, S. (2017). Azadirachta indica A. Juss: safety and efficacy during pregnancy and lactation. Int. J. Nur. Care., 1(5), 1-4.

Keshri, G.; Lakshmi, V.; Singh, M.M. (2003). Pregnancy interceptive activity of Malia azedarach L. in adult female rats. Contaception., 68, 303- 306.

Khare, A.K.; Srivastava, N.C.; Sharma, M.K.; Jewari, J.P. (1984). Antifertility activity of Neem oil in rabbits and rats. Probe., 23, 90- 93.

Kumar, R.V.; Reddy, V.R.; Sathyanarayana, J.; Bikshapathi, T.; Reddy, M.K. (2013). Effect of Melia azedarach and Dodonaea Viscosa aqueous leaf extracts in fertility in male albino rats. Indian J. Pharm. Biol. Res., 1(4), 7-12.

Luna, H.C. (1968). "Manual of Histological Staining Methods of the Armed Force Institute of Pathology". $3^{\text {rd }}$ MCGrow- Hill Book Co. New York. 258 p.

Mandal, R.; Dhaliwal, P.K. (2007). Antifertility effect of Melia azedarach Linn (dharek) seed extract in female albino rats. Indian J. Exp. Biol ., 45, 853- 860.

Mishra, P.K.; Singh; S.K. (2005). Effect of aqueous leaf extract of Azadirachta indica on the reproductive organs in male mice. Indian J. Exp. Biol., 43(11), 1093- 1103.

Mukherjee, S.; Garg, S.; Talwar, G.P. (1999). Early post-implantation contraceptive effects of purified fraction of Neem (Azadirachta indica) seed, given orally in rats. $J$. Ethnopharmacol ., 67, 287-296.

Nahak, G.; Saho, R.K. (2010). In vitro antioxidative activity of Azadirachta indica and $M$. azedarach by DPPH scavenging assay. Nat Sci., 8(4), 22- 28.

Parshad, O.; Singh, P.; Gardner, M.; Flectcher, C.; Rickards, E.; Choo- kang, E. (1994). Effect of aqueous neem (Azadirachta indica) extract on testosterone and other blood constituents in male rats. a pilot study. West Indian Med. J., 43, 71-74.

Parshad, V.R.; Ahmad, N. (1996). Rodent Pest management in agriculture: Problems strategies and implementation. J. Res. Punjab Agric. Univ., 33, 266- 281.

Ragi, Y.; Udoh, U.S.; Mewoyeka, O.O.; Ononye, F.C; Bolarinwa A.F. (2003). Implication of Reproductive endocrine malfunction in male antifertility efficacy of Azadirachta indica in rats. Afr. J. Med. Sci., 32, 159- 165.

Rana, A.C.V. (2010). Evaluation of hydroalcoholic extract of M. azedarach Linn root for analgesic and anti- inflammatory activity. Int. J. Phytomed., 2(3), 341- 344.

Roop, J.K.; Dhaliwal, P.k.; Garaya, S.S. (2005). Extracts of Azadirachta indica and Melia azedarach seeds inhibit folliculo-genesis in albino rats. J. Med. Biol. Res., 38(6), 943947.

Roop, J.K.; Dhaliwar, P.K. (2015). Effect of Melia azedarach linn. seed extract of estrous cycle and reproductive performance in female rats. inter. J. Pharm. Tech. Res., 8(2), 273- 279.

Shaher, W.S. (2009). Effect of Azadirachta excelsa (Jack) leaf extracts on reproductive organs and fertility of male abino mice (Mus Musculus). J. Raf. Sci., 20(3), 1-9. 
Shaher, W.S. (2013). Some Histo-phiysiologycal effects of Azadirachta excelsa (Jack) leaf extract on reproductive organs and fertility of female albino mice (Mus Musculus). J. Raf. Sci., 24 (6), 1-9.

Srinvasa Rao, A.; Ahmed, M.F.; Ibrahim, M. (2012). Hepatopratective activity of Melia azetarach leaf extract against simvastation induced Hepatotoxicity in rats. J. Applied Pharmaeol. Sci., 2(7), 144- 148.

\section{Mus musculus تأثير مستخلص اورلق السبحبح على نسيج الخصية في الفئران المهقاء}

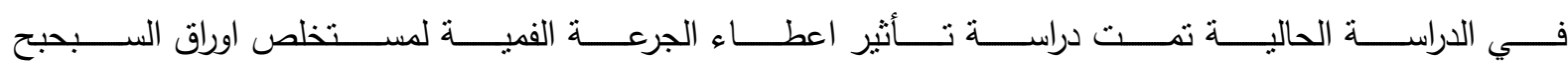

Melia azedarach لذكور الفئران.

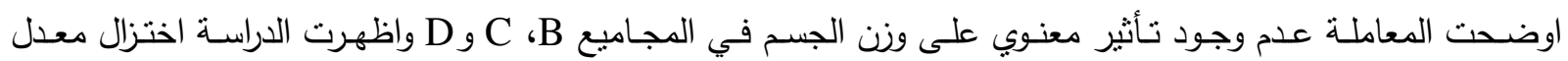
الولادات والخصوبة الى 2.66 و66.66 \% في المجاميع المعاملة لمدة 7 اسابيع على التوالي.

لوحظت التغييرات النسجية المرضية في مقاطع الخصى في جميع المعاملات لذكور الفئران وان درجة ومدى هذه التغييرات من المتوسطة الى الحادة.

تضمنت النتائج حصول فصل ونخر للنبيبات المنوية، وخزب في نسيج الخصى، مزج وتغيرات نخريـة للخلايا المكونـة للنطف، تتكس وفقدان اجزاء من الطبقة المولدة للنطف في النبيبات المنوية.

كما اظهرت النتائج حصول نزف للخلايا البينية بين النبيبات المنوية وتكتل الحيوانات المنوية في تجويف النبيبات المنوية وتثخن جدران الغلاف الابيض للخصى.

الكلمات الدالة: .Melia azedarach L. مستخلص اوراق السبحبح، الخصية، الخصوبة، الفئران. 